\title{
Aortic occlusion in systemic lupus erythematosus associated with antiphospholipid antibodies
}

\author{
P DREW, ${ }^{1}$ R A ASHERSON, ${ }^{2}$ R J ZUK, ' F J GOODWIN, ' AND G R V HUGHES \\ From the 'Department of Nephrology and Morbid Anatomy, The London Hospital, Whitechapel; and the \\ ${ }^{2}$ Lupus Arthritis Research Unit, The Rayne Institute, St Thomas's Hospital, London
}

SUmmary The patient, a Caucasian woman of 22 years, developed malignant hypertension a the age of 16 years. An abdominal bruit was found on routine examination. She had two spontaneous abortions and systemic lupus erythematosus was diagnosed at age 21 years. She was found to have a persistently low positive VDRL and antibodies to mitochondria were also presen on repeated examinations, to a titre of $1 / 160$. Because of angiographic findings, demonstrating ans occlusion of the aorta, an endarterectomy of the descending thoracic and upper abdominal aorta was performed. This showed mainly intimal thickening and the presence of thrombus. She therpo had four further spontaneous abortions (with good blood pressure control). The lupusi anticoagulant and antibodies to cardiolipin were found to be positive at this time.

Key words: aortic coarctation, recurrent abortions.

The thrombotic manifestations occurring in association with the antiphospholipid antibodies ('lupus anticoagulant', antibodies to cardiolipin and the false positive test for syphillis-Venereal Disease Research Laboratory (VDRL)) are usually found in the venous system. ${ }^{1}{ }^{2}$ They include, not only deep vein thromboses, affecting mainly leg veins, but other veins as well, such as renal, ${ }^{3}$ axillary, ${ }^{4}$ or superficial thrombophlebitis. ${ }^{5}$ Retinal vein occlusions, uncommon in systemic lupus erythematosus (SLE), have also been reported in association with these antibodies, and in these patients they occurred together with retinal arterial involvement. ${ }^{67}$

Large vessel arterial occlusions are unusual in SLE and may be vasculitic in origin. Vasculitis is also usually responsible for smaller vessel distal infarctions which occur in the vicinity of the nail fold. Occasionally they may be more extensive, resulting in larger gangrenous areas of the fingers or toes.

It has become evident since the introduction of

Accepted for publication 27 February 1987.

Correspondence to Dr R A Asherson, The Rayne Institute, St Thomas's Hospital, London SE1 7EH. the anticardiolipin antibody test that there are patients who do not have vasculitic lesions or histological examination who have raised levels of. anticardiolipin antibodies, show the presence of the 'lupus anticoagulant', and perhaps show othe? manifestations of the antiphospholipid syndrome. ${ }^{8}$ 罗 These patients present with or develop large vessed occlusive disease during the course of classical SLE or even more commonly during a 'lupus-like illness. ${ }^{10}$

\section{Case report}

In 1971 a 16 year old girl presented to hospitâ complaining of severe headaches and was found to have malignant hypertension. Apart from a blood pressure of $200 / 150 \mathrm{mmHg}$ and a grade IV hyper tensive retinopathy she was also noted to have alf abdominal bruit. Preliminary investigations showe normal plasma urea and electrolytes, a negativ VDRL test, and normal chest $x$ ray and intravenous pyelogram (IVP). Both the patient and her parents declined further investigations at this stage. Hew blood pressure was well controlled by treatment with methyldopa and a thiazide diuretic, and she was discharged for outpatient review. 
Over the next few years she suffered intermittently from depression. Methyldopa treatment was withdrawn and blood pressure satisfactorily controlled with diuretic therapy alone, but despite

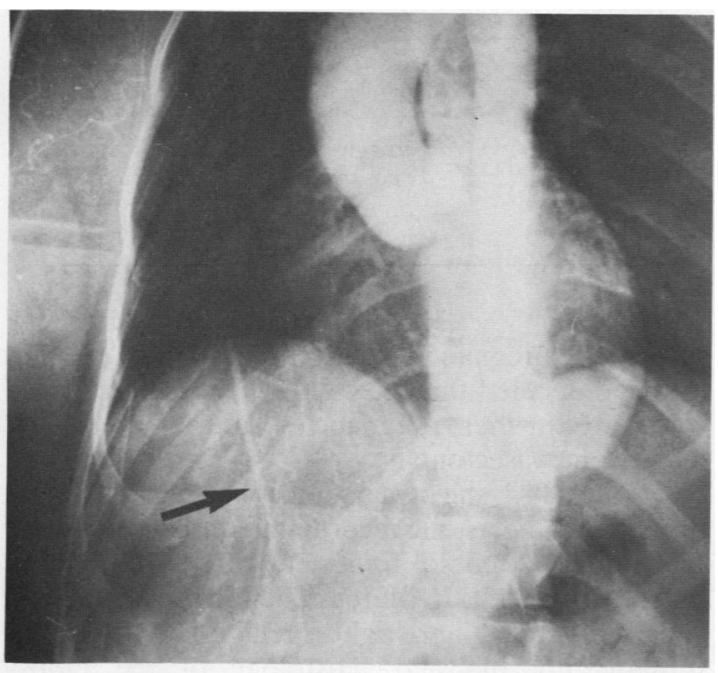

Fig. 1a

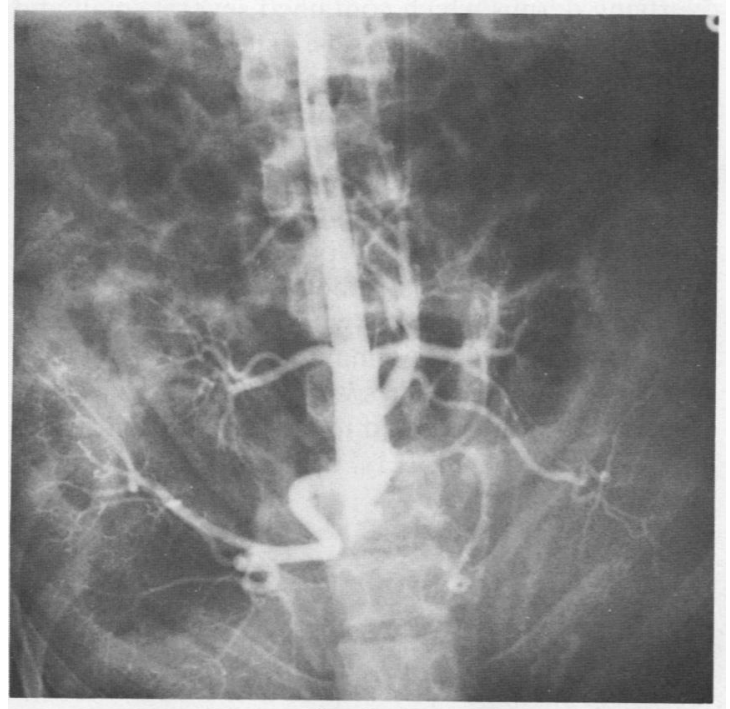

Fig. 1b

Fig. 1 (a) Proximal aortography showed occlusion of the aorta just above the diaphragm (partly obscured by the spine in the photograph) with dilatation of the proximal aorta and a collateral circulation. The internal mammary artery is marked with an arrow. (b) Distal aortography showed patent renal arteries but occlusion of the aorta just above the level of the coeliac axis. This distal aorta appears hypoplastic and the splenic artery is enlarged. this she required periods of psychiatric treatment. She married, but after an unsuccessful pregnancy, which was complicated by hypertension, she was referred to The London Hospital for a second opinion. When seen she was pregnant for the second time and hypertensive with systolic blood pressure recordings greater than $200 \mathrm{mmHg}$ in both arms. Again she was noted to have a loud abdominal bruit and was found to have greatly diminished pulses in both legs. Systolic pressures in both legs were recorded at less than $100 \mathrm{mmHg}$. There was no evidence of exudative retinopathy and routine urine analysis was normal. She was admitted to hospital and subsequently had a spontaneous abortion. Further investigations showed normal renal function; VDRL test positive 1/4; fluorescent treponemal antibody (FTA) test and Treponema pallidum haemagglutination (TPHA) test negative; the antinuclear factor (ANF) diffuse positive at 100 $\mathrm{U} / \mathrm{ml}$; antimitochondrial antibodies positive $1 / 160$; deoxyribonucleic acid (DNA) binding normal; diffuse hypergammaglobulinaemia on serum electrophoresis; reduced levels of serum complement, with $\mathrm{C} 4$ component of $70 \mathrm{mg} / \mathrm{l}$ (normal range 200-550 mg/l) and $\mathrm{CH}_{50}$ of $27 \mathrm{U} / \mathrm{ml}$ (normal range $30-50 \mathrm{U} / \mathrm{ml}$ ) but slightly raised $\mathrm{C} 3$ component at $1550 \mathrm{mg} / \mathrm{l}$ (normal range 650-1450 mg/l) (Table 1). Selective renal arteriography showed no evidence of a renal artery stenosis, but aortography showed almost complete obliteration of the aorta over a $6 \mathrm{~cm}$ segment immediately above the take off of the coeliac axis. The lower intercostal arteries on the left and the internal mammary artery on the right were found to be moderately dilated, supplying a collateral circulation around the obliterated segment of the aorta (Figs 1a and b).

In May 1979 an endarterectomy of the descending thoracic and upper abdominal aorta was performed, a large section of grossly thickened cartilaginous vessel was removed and a Dacron patch inserted over the defect. Histology of the resected specimen showed that it was mostly intima, thickened with fibrous tissue and focal calcification and with adherent recent thrombus. There were no other diagnostic features (Fig. 2).

Postoperatively, her blood pressure fell to levels of around $110 / 80 \mathrm{mmHg}$, and she required no drug treatment. Over the next four years she had three spontaneous abortions; none of the pregnancies were associated with development of high blood pressure. Further investigations were performed and included VDRL positive 1/16; FTA and TPHA negative, ANF positive 1/40, with nucleolar pattern; antimitochondrial antibodies positive 1/40); DNA binding $21 \mathrm{U} / \mathrm{ml}$, repeated $10 \mathrm{U} / \mathrm{ml}$ (normal range 0 $-25 \mathrm{U} / \mathrm{ml}$ ); IgM anticardiolipin antibodies strongly 
Table 1 Laboratory investigations

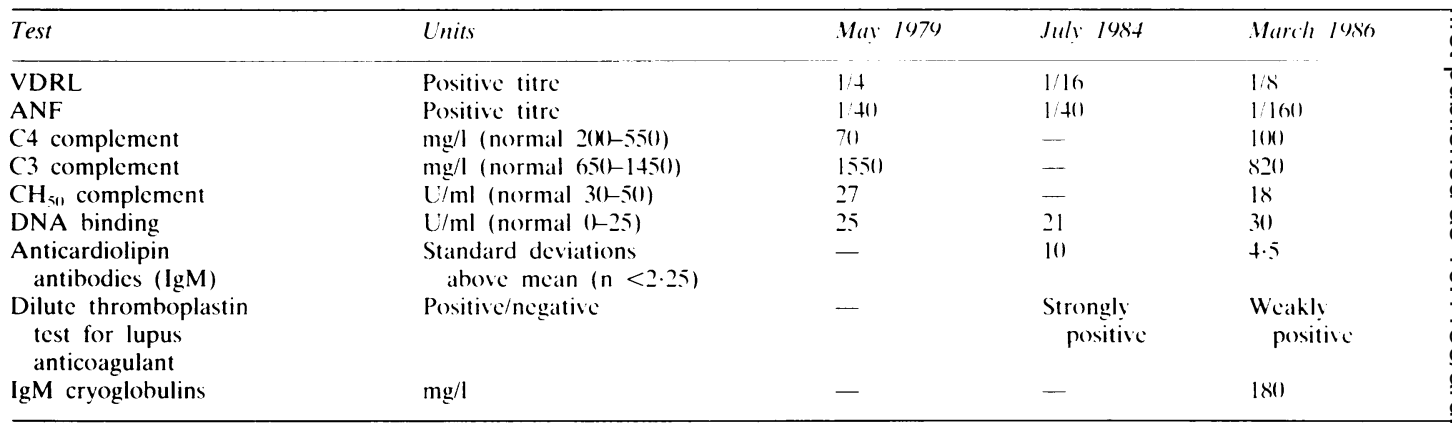

positive, IgG anticardiolipin antibodies negative: dilute thromboplastin test for lupus anticoagulant positive (Table 1). During the course of these investigations she was found to have carcinoma in situ of the uterine cervix and underwent cone biopsy. Consideration was given to the possibility of steroid treatment in an attempt to produce a

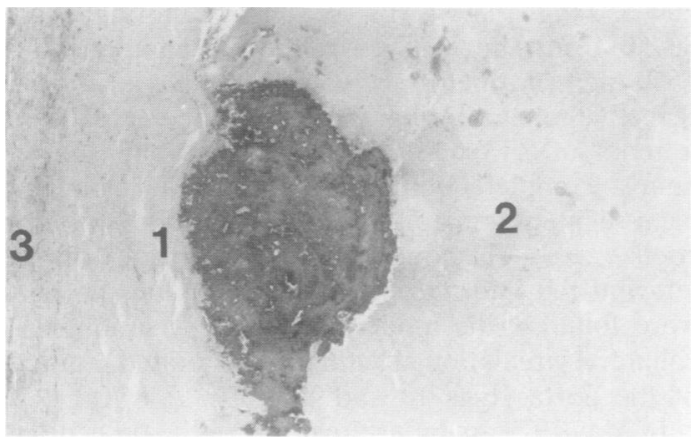

Fig. 2 Representative area of endarterectomy specimen showing (I) thickened fibrotic intima with focal calcification; (2) adherent recent thrombus; (3) thin outer rim of media. successful pregnancy, but the patient and heis husband decided that they did not want to proceet with any further pregnancies and her husbans underwent vasectomy.

During 1984 she again developed a high bloo pressure with diastolic recordings consistently above $100 \mathrm{mmHg}$. Atenolol treatment was started with $\mathrm{c}^{+}$ satisfactory result. In March 1986 she presented witbo an ulcer under her right great toe which was subsequently biopsied. Histology of the biopse specimen showed an area of epidermal necrosis overlying dermis which contained several small and medium sized blood vessels. There was marked perivascular mononuclear cell infiltration witf destruction of vessel walls. Two medium sized veins contained organising thrombi and also appeared t? be involved in the vasculitic process. No fibrinois necrosis was seen (Fig. 3). Further investigations 屏 this stage confirmed the presence of the lupis anticoagulant and again showed the serum ANE positive at a titre of $1 / 160$ with a nucleolar patterio DNA binding was minimally raised at $30 \mathrm{U} / \mathrm{m}$. Anticardiolipin antibodies were positive and an IgN cryoglobulin was detected in a concentration of 18 通 $\mathrm{mg} / \mathrm{l}$. Serum $\mathrm{C} 4$ and $\mathrm{CH}_{50}$ complement were agaig

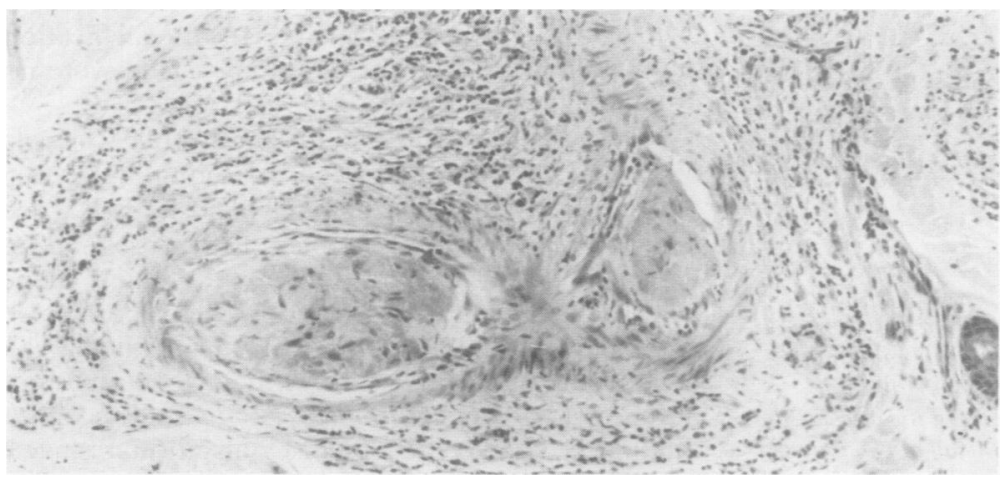

Fig. 3 Representative area of dermis showing two medium sized veins containing organising thrombi and marked perivascular mononuclear cell infiltration. 
found to be reduced, but serum $\mathrm{C} 3$ complement was normal (Table 1). Atenolol treatment was stopped and hypertension controlled with a small dose of enalapril. Treatment with prednisolone and azathioprine was started, and the ulcer slowly healed over the next few weeks. After six months' immunosuppressant treatment there was no further ulceration, though she had developed several tender, non-ulcerating nodules on the underside of her toes, which have resolved without further intervention. Blood pressure was satisfactorily controlled at $140 / 90 \mathrm{mmHg}$ by treatment with enalapril $5 \mathrm{mg} /$ day, and systolic blood pressure was the same in all four limbs. Repeat tests for cryoglobulins have been performed and show that these are still detectable but at a lower concentration of $72 \mathrm{mg} / \mathrm{l}$.

\section{Discussion}

The patient reported is a unique case. She had persistently positive 'lupus anticoagulant' and antibodies to cardiolipin and a false positive VDRL test over a number of years. The manifestations of the 'antiphospholipid syndrome' in her case included five spontaneous abortions but, more importantly, obliteration of a $6 \mathrm{~cm}$ segment of the aorta immediately above the take off of the coeliac axis. Aortography demonstrated the probable presence of a collateral circulation via the lower left intercostal arteries and the right internal mammary artery (Figs 1a and b). There had been no evidence of renal artery stenosis, but hypertension had been a problem since the age of 16 . Ulceration of the toes which occurred subsequently was proved by biopsy to be due to a vasculitic process.

The histology of the resected portion of the vessel showed thickened intimal tissue demonstrating fibrosis and focal calcification with adherent recent thrombus. There was no evidence of aortitis (Fig. 2).

This case represents the first record of a patient who developed aortic occlusion in association with antiphospholipid antibodies. Lesions of the aorta and its branches in SLE have been infrequently reported and are considered as distinctly rare. A report of Lessof and Glynn in 1959 appears to have been the first recorded case of this association, and their patient presented with a 'pulseless syndrome' affecting the upper extremities. ${ }^{1}$ Interestingly, that patient showed a false positive Wassermann reaction.

Ferrante et al described a 19 year old woman with a left subclavian artery occlusion, ${ }^{12}$ and Asherson $e t$ al in 1985 reported a similar patient, who had the lupus anticoagulant, antibodies to cardiolipin, and a false positive VDRL test. ${ }^{13}$ This patient has since developed recurrent cerebral infarctions and multiinfarct dementia, a not uncommon development in these patients. ${ }^{14}$ Another similar patient recently treated by the same group went on to develop gangrene and required amputation of three digits of her left hand. ${ }^{15}$ Six patients with large vessel occlusions and gangrene in SLE, four of whom demonstrated antiphospholipid antibodies, were recently recorded by Asherson et al, ${ }^{16}$. who also described mesenteric occlusions in association with these antibodies. ${ }^{17} 18$ In all patients where histological material was available no evidence of vasculitis was found. Usually the pathology showed the presence of thrombus and severe intimal proliferation similar to that seen in the present case.

The commonest site for arterial occlusions in association with antiphospholipid antibodies is the cerebral vasculature, ${ }^{19}$ the middle cerebral artery being most frequently affected, but often multiple vessels are occluded ${ }^{2021}$ and a variety of central nervous system (CNS) symptomatology is encountered. Transient ischaemic attacks, recurrent strokes, and epilepsy are commonly seen. Migraines are a frequent prodrome or accompaniment of these events. $^{8}$ Whether the other CNS symptomatology such as chorea, transverse myelitis, Guillain-Barré syndrome, or optic neuritis occur on an ischaemic basis or are due to antigen-antibody reaction between brain antigens and antiphospholipid antibodies is unclear. ${ }^{9}$

Takayasu's arteritis can cause a similar clinical picture. Upper abdominal aortic involvement is usually asymptomatic, whereas lower abdominal narrowing may result in intermittent claudication or even gangrene. ${ }^{22}$ In addition to the case described by Lessof and Glynn, ${ }^{11}$ LE cells have been reported in two other early cases. ${ }^{23}$

Takayasu's arteritis presents a different picture from the present case. Necrosis and fragmentation of the elastic tissue of the media and internal laminae are associated with an irregular pan arteritis with perivascular round cell infiltration in the adventitia. Occasionally granulomatous changes (including multinucleated giant cells) may be demonstrable within the media and calcification may be found. Superimposed atheromatous changes are usually present. ${ }^{22}$

\footnotetext{
References

1 Bocy M L. Colaco C B. Gharavi A E. Elkon K B. Loizou S. Hughes $G R$ V. Thrombosis in systemic lupus ersthematosus: striking association with the presence of circulating lupus anticoagulant. $\mathrm{Br}$ Med J 1983: 287: 1121-3.

2 Harris E N. Gharavi A E. Bocy M L. e' al. Anticardiolipin antibodics: detection by radioimmunoassaly and association
} 
with thrombosis in systemic lupus erythematosus. Lancet 1983; ii: $1211-4$.

3 Asherson R A, Lanham J G, Hull R G, Bocy M L, Gharavi A $E$, Hughes $G R$ V. Renal vein thrombosis in systemic lupus erythematosus. Clin Exp Rheumatol 1984: 2: 75-9.

4 Bowie E J W, Thompson J H J, Pascuzzi C A. Owen C A Jr. Thrombosis in systemic lupus erythematosus despitc circulating anticoagulants. J Lab Clin Med 1963; 3: 416-30.

5 Peck B, Hoffman G S, Francis W A. Thrombophlebitis in systemic lupus erythematosus. JAMA 1978; 240: 1728-30.

6 Hall S, Buettner H. Lutnra H S. Occlusive retinal vascular disease in systemic lupus erythematosus. Ann Intern Med 1984: 11: $846-50$.

7 Vermylen J, Blockmans D. Spitz B, Deckmyn H. Thrombosis and immune disorders. Clin Haematol 1986: 15: 1-17.

8 Hughes G R V. Harris E N. Gharavi A E. The anticardiolipin syndrome. $J$ Rheumatol 1986; 13: 486-9.

9 Asherson R A. Harris E N. Antiphospholipid antibodiesclinical associations. Postgrad Med J 1987; 62: 1081-7.

10 Asherson R A. Harris E N. Gharavi A E. Clinical and laboratory features associated with anticardiolipin antibodies in non-SLE patients [Abstract]. Arthritis Rheum 1985; 28: S77.

11 Lessof M H, Glynn L E. The pulseless syndrome. Lancet 1959; i: $799-801$.

12 Ferrante M F. Myerson G E. Goldman J A. Subclavian artery thrombosis mimicking the aortic arch syndrome in systemic lupus erythematosus. Arthritis Rheum 1982; 25: 1501-4.

13 Asherson R A. Harris E N. Gharavi A E. Hughes G R V. Aortic arch syndrome associated with anticardiolipin antibodies and the "lupus anticoagulant". Arthritis Rheum 1985; 38: 594.

14 Asherson R A. Mercey D. Phillips G. Shechan N. Harris E N. Hughes G R V. Recurrent stroke and multi-infarct dementia in systemic lupus erythematosus: association with antiphos pholipid antibodies. Ann Rheum Dis 1987: 46: 605-11.

15 Asherson R A. Ridley M. Longhurst H, Jamieson C W. Davies $\overrightarrow{\bar{F}}$ D. Hughes G R V. Antiphospholipid antibodics and large? vessel arterial occlusions in SLE. J Vasc Surg (in press).

16 Asherson R A. Derksen R H W M. Harris E N. et al. Largco vessel occlusions and gangrene in systemic lupus erythematosus and 'lupus-like" disease. A report of six cases. $J$ Rheumato $\vec{\Phi}$ 1986: 13: 740-7.

17 Asherson R A. Morgan S H, Harris E N. Gharavi A E. Kraus $T$. Hughes $G R$ V. Arterial occlusion causing large bowel infarction-a reflection of clotting diathesis in SLE. Clin $\overrightarrow{0}$ Rheumatol 1985: 5: 102-6.

18 Asherson R A. Mackworth-Young C G. Harris E N. Gharavi A E. Hughes G R V. Multiple venous and arterial thromboses associated with the lupus anticoagulant and antibodies to cardiolipin in the absence of SLE. Rheumatol Int 1985; 5: 91-3.?

19 Harris E N, Gharavi A E. Asherson R A. Bocy M L. Hughes G $R \mathrm{~V}$. Cerebral infarction in systemic lupus: association withoo anticardiolipin antibodies. Clin Exp Rheumatol 1984: 2: 47-51

20 Derksen R H W M. Bouma B N. Kater L. The association between the lupus anticoagulant and cerebral infarction in systemic lupus erythematosus. Scand J Rheumatol 1986; 15. $179-84$.

21 Hart R G, Miller V T. Coull B M, Bril V E. Cerebral infarctionD associated with lupus anticoagulants-preliminary reportê Stroke 1984; 15: 114-8.

22 Schrire V. Asherson R A. Arteritis of the aorta and its major branches. $Q J$ Med 1964: 132: 439-62.

23 Judge R D. Currier E D. Gracic W A. Figley M H. Takayasu ' 00 arteritis and the aortic arch svndrome. Am J Med 1962; 32: 379-92. 